Omni-Akuatika, 14 (1): 44-53, 2018
ISSN: 1858-3873 print / 2476-9347 online
Research Article
journal homepage: http://ojs.omniakuatika.net

\title{
The Role of Turmeric Powder Supplementation in Improving Liver Performances to Support the Production of Siam Catfish (Pangasianodon hypophthalmus)
}

\author{
Cut Dara Dewi ${ }^{1}$, Wasmen Manalu ${ }^{1,{ }^{*}}$, Damiana Rita Ekastutii ${ }^{1}$, Agus Oman Sudrajat ${ }^{2}$ \\ ${ }^{1 *}$ Department of Anatomy, Physiology, and Pharmacology, Faculty of Veterinary Medicine, Bogor Agricultural \\ ${ }^{2}$ Department of Aquaculture, Faculty of Fishery and Marine Sciences, Bogor Agricultural University, Indonesia
}

"Corresponding author: wasmenmanalu@ymail.com

Received 20 March 2018; Accepted 5 May 2018; Available online 28 May 2018

\begin{abstract}
In oviparous animals, the qualities of offspring are determined by the materials deposited in the developing oocytes that are synthesized and produced by the hepatocytes under the control of estrogen. This study was designed to evaluate the effect of turmeric powder supplementation on liver performance to support the reproduction performances of catfish. The study used 60 catfish with average body weight of $\pm 2 \mathrm{~kg}$. The experimental catfish were assigned into a completely randomized design with 4 treatments and each treatment consisted of 15 replications. The treatment was the dose of turmeric powder supplementation in the commercial feed i.e., 0, 240, 480, and $960 \mathrm{mg} / 100 \mathrm{~g}$ feed. The experimental catfish were fed two times a day in the morning and in the evening as much as $3 \%$ of body weight. The results showed that turmeric powder supplementation at a dose of $240 \mathrm{mg} / 100 \mathrm{~g}$ feed could inhibit liver cell destruction in the catfish as was indicated by the increase in body weight, liver weight, and DNA concentrations of liver, as well as the decrease in the liver malondialdehyde, serum glutamic pyruvic transaminase, and serum glutamic oxaloacetic transaminase concentrations. Turmeric powder supplementation can be used in oviparous animals and fish to increase liver function and capacity to synthesize vitellogenin to be deposited in the developing follicles during reproduction phase.
\end{abstract}

Keywords: turmeric powder; catfish (Pangasianodon hypophthalmus); serum glutamic piruvic transaminase (SGPT); serum glutamic oxaloacetic transaminase (SGOT)

\section{Introduction}

The production of catfish in Indonesia shows a pattern of increase every year, even though the level of production achieved has not reached the production target. The effort to increase catfish production has been conducted, however, to reach the optimum production it is required to optimize the physiological functions of body organs, including liver functions. Under the control and regulation of estrogen, livers are the main organs that synthesize and produce the vitellogenin deposited in the egg yolk that will determine the quality and production of follicles and oocytes that eventually will determine the quality of larvae and offspring produced. Liver is an organ that supports the functions of other organs in the body, and also an organ having various metabolic functions and provides enzymes required for body metabolism, detoxification of toxic materials, to produce several hormones and other compounds that eventually affect and decrease the liver functions. With these various functions, the liver has a great chance to experience hepatotoxicity that decreases the whole liver functions and causes pathological conditions (Echols, 2006) that eventually affect the health, reproduction, and productivity.

The increase in lipid peroxidation and the high production of free radicals can produce and initiate the oxidative stress conditions. Lipid peroxidation will increase the concentrations of malondialdehyde (MDA) in the liver as an end product of lipid peroxidation. The increased MDA in the liver is an indicator of lipid peroxidation and secondary inhibition of endogenous antioxidant enzymes in the liver. The concentrations of serum glutamic pyruvic 
transaminase (SGPT) and serum glutamic oxaloacetic transaminase (SGOT) enzymes are also increase with the decreased endogenous antioxidant concentrations. These two enzymes, SGPT and SGOT, are markers used to measure the decrease in liver functions (Gorman et al., 2008; Bigoniya et al., 2009). The increase in SGPT and SGOT enzymes above the normal levels can be used as an indicator of destruction of liver cells (Aggarwal et al., 2006). The blood concentrations of SGOT and SGPT increased with the increase in age (Biswas et al., 2010).

Turmeric (Curcuma longa) is a herbal plant having various effects and uses in traditional medicine. The chemical contents of turmeric rhizome are volatile oils, curcumin, monodesmetoxycurcumin, and bidesmetoxycurcumin. It is known that curcumin can improve the liver functions through the stimulation of liver cells regeneration and protect the liver cells from the toxic effects of compounds that can destroy liver cells. Turmeric has some pharmacological effects such as anti-inflammation, antioxidant, antibacterial, and immune-stimulant (Aggarwal et al., 2006). Curcumin has antioxidant activities and inhibits lipid peroxidation (Kohli et al., 2005). Curcumin is an active compound in the turmeric that has activity as a hepatoprotector that can prevent the destruction of liver cells (Somchit et al., 2005) that eventually affects the liver functions.

Various techniques and methods were conducted to maintain and improve the production performances of catfish. The improved and increased functions of liver cells play significant roles to support body metabolism in general and specifically to support the synthesis of vitellogenin during the phase of gonad maturity and reproduction phases. Our previous study showed that turmeric powder supplementation in the ration dramatically increased the capacities of catfish to synthesize vitellogenin that significantly increased vitellogenin deposition in the growing and developing oocytes that eventually increased the number of ovulating follicles with a significantly higher diameter of ovulated oocytes (Dewi et al., 2018a,b). The increase in vitellogenin deposition in the oocytes will improve the larvae quality produced that eventually improves the growth and development until maturity. The present experiment was designed to study the effects of turmeric powder supplementation on the improvement of liver cells functions by measuring the parameters of serum glutamic pyruvic transaminase (SGPT) and serum glutamic oxaloacetic transaminase (SGOT) as indicators of the lyses of hepatocytes or liver cells, DNA concentrations in the liver tissue as an indicator of the populations of liver cell per gram of liver tissues, RNA concentrations in the liver tissue as an indicator of synthetic activities and capacities of liver cells, malondialdehyde (MDA) concentrations in the liver tissue as an indicator of the activity of oxidative stress in the liver, and concentrations of endogenous antioxidant superoxide dismutase (SOD) as an indicator of antioxidant condition of the liver tissue.

\section{Materials and Methods}

\section{Location and time of study}

The experiment was conducted in October-December 2016. The catfish maintenance during the experiment was conducted in Aquaculture Development of Pangasius and Clarias Catfish (ADPCC), Cijengkol, Subang, West Java, Indonesia. The analyses of SGPT, SGOT, as well as the DNA, RNA, MDA, and SOD concentrations in the liver tissue were conducted in the Laboratory of Physiology, Department of Anatomy, Physiology, and Pharmacology, Faculty of Veterinary Medicine, Bogor Agricultural University, Bogor, Indonesia. Histological analysis of liver was conducted in Subang Veterinary Institute, Subang, West Java.

\subsection{Ration used}

The experimental catfish were fed with commercial ration with protein concentration of $28 \%$. As a treatment, the turmeric powder was mixed with the commercial ration according to the dose of turmeric powder supplementation. Turmeric powder used in the experiment was obtained from Research Institute for Medicinal and Aromatic Plants, Cimanggu, Bogor. The process of feed coating was started with the addition of carboxymethyl cellulose (CMC) powder as a binder to the commercial feed. The level of CMC addition was $10 \%$ in the commercial feed used. Further, the turmeric powder was added into the commercial feed mixed with CMC. The doses of turmeric powder supplementation in the experimental diet were $0,240,480$, and $960 \mathrm{mg} / 100 \mathrm{~g}$ commercial feed according to the treatment. Turmeric powder supplementation was conducted by mixing the turmeric powder into the commercial feed mixed with CMC and the mixture were then sprayed with water. The experimental diets were then dried in room condition without direct sun drying. 


\section{The maintenance of experimental catfish}

The experiment and the maintenance of experimental catfish were conducted in Aquaculture Development of Pangasius and Clarias Catfish (ADPCC), Cijengkol, Subang, West Java, Indonesia. Sixty female catfish (Pangasionodon hypophthalmus) were maintained in the maintenance pool with the size of $7 \times 5 \times 1.5 \mathrm{~m}^{3}$. The average body weights of experimental catfish at the beginning of experiment were $2.55 \pm 0.21,1.91 \pm 0.05$, $2.15 \pm 0.16$, and $1.91 \pm 0.05 \mathrm{~kg}$ for catfish supplemented with turmeric powder at doses of $0,240,480$, and $960 \mathrm{mg} / 100 \mathrm{~g}$ feed, respectively. At the beginning of experiment, catfish supplemented with turmeric powder at doses of 0 and $480 \mathrm{mg} / 100 \mathrm{~g}$ feed had higher body weights compared to catfish supplemented with turmeric powder at doses of 240 and $960 \mathrm{mg} / 100 \mathrm{~g}$ feed $(p=0.000)$. The selected catfish were adapted to maintenance pond for 1 month prior to treatment. During maturation and ovulation, the experimental catfish were maintained in 4 experimental ponds each with the size of $7 \times 5 \times 1.5 \mathrm{~m}^{3}$. Fifteen experimental catfish were maintained and raised in each experimental pond. The experimental catfish were maintained and given the treatment by feeding with the experimental feeds supplemented with various doses of turmeric powder $(0,240,480$, or $960 \mathrm{mg} / 100 \mathrm{~g}$ feed) for 12 weeks, or 3 months, 2 times a day in the morning and in the afternoon. The level of feeding given was around $3 \%$ of body weights of experimental catfish.

\section{Experimental design}

The experimental catfish were assigned into a completely randomized design consisted of 4 treatments and each treatment used 15 experimental catfish. The treatment was the dose of turmeric powder supplementation in the commercial ration. The first treatment was commercial feed supplemented with turmeric powder at a dose of $0 \mathrm{mg} / 100 \mathrm{~g}$ feed as a control. The second treatment was commercial feed supplemented with turmeric powder at a dose of $240 \mathrm{mg} / 100 \mathrm{~g}$ feed. The third treatment was commercial feed supplemented with turmeric powder at a dose of $480 \mathrm{mg} / 100 \mathrm{~g}$ feed. The fourth treatment was commercial feed supplemented with turmeric powder at a dose of $960 \mathrm{mg} / 100 \mathrm{~g}$ feed.

The high quality of the water media was maintained under controlled conditions during the experiment. The water temperature ranged from 27 to $30^{\circ} \mathrm{C}$; the $\mathrm{pH}$ ranged from 7 to 7.5 ; and the dissolved oxygen from 5.4 to $6.5 \mathrm{mg} / \mathrm{L}$.
The standard water temperature, $\mathrm{pH}$ and dissolved oxygen ranges are 28 to $30^{\circ} \mathrm{C}, 6.85$ to 7.5 and 3.0 to $6.0 \mathrm{mg} / \mathrm{L}$.

\section{Parameters measurements}

At the end of 12 weeks of turmeric powder supplementation, the experimental catfish were sacrificed to observe and measure liver tissues. Prior to being sacrificed, each experimental catfish was weighed for measuring body weight at the end of treatment. Blood samples and liver organs were collected at the end of experiment. Each group of dose of turmeric powder supplementation was represented by 3 catfish to be sacrificed. Five milliliters of blood sample was drawn from the blood vessels in the caudal part of the body in the tail of experimental catfish by using syringe containing anticoagulant $(3.8 \%$ of sodium citrate). The blood samples were collected in glass tubes and put in a non-vertical position for 1-2 hours to separate the plasma from the blood cells. The blood samples were centrifuged at the 3000 rpm for 10 minutes. The separated plasma was transferred and saved in micro tube (eppendorf tube) and stored at a freezer at the $-20{ }^{\circ} \mathrm{C}$ for further analyses of SGPT and SGOT with the method of Reitman and Frankel (Bigoniya et al., 2009). Further, the liver organs was isolated and then stored in $10 \%$ of buffered neutral formalin for histological preparation.

Qualitative observations of liver tissues was determined from the description of histological observations of the liver by using paraffin and Hematoxcyline-Eosine staining (Bancroft and Gambel, 2008). Liver organs used for measuring DNA, RNA, MDA, and SOD concentrations were stored in freezer. For measurement of MDA and SOD concentrations in the liver tissues, $3 \mathrm{~g}$ of liver tissue were used in the preparation of the samples by following the method of TBA (thiobarbiturate) (Capeyron et al., 2002). For measurement of DNA and RNA concentrations in the liver tissues, 2-3 $\mathrm{g}$ of liver tissue were used and dried in the oven at $60{ }^{\circ} \mathrm{C}$ for 3 days or until dry, and the dried liver tissues were processed into a powder. Ten milligrams of the liver samples were used for measurements of DNA and RNA concentrations in the liver tissue. The DNA concentrations of liver tissue were determined by DNA extraction method by using genomic DNA mini kit (Geneaid GT050), while the concentrations of RNA in the liver tissues were determined by following the procedure recommended by Manalu and Sumaryadi (1998). 


\section{Data analyses}

The collected data were analyzed by using Microsoft excel 2010 program and SPSS version 16.0 to calculate the analyses of variance of the data. When the effect of treatment was significant, the different between treatments were tested by using Duncan test.

\section{Results and Discussion}

Turmeric powder supplementation in the commercial feed improved the growth rate of experimental catfish during 12 weeks of turmeric powder supplementation as was indicated by the increased absolute body weight gain $(p=.000)$ (Table 1). At the end of 12 weeks of turmeric powder supplementation, the experimental catfish supplemented with turmeric powder at a dose of $240 \mathrm{mg} / 100 \mathrm{~g}$ feed had the highest absolute body weight gain compared to catfish supplemented with turmeric powder at doses of $0(p=0.000), 480(p=$ $0.012)$, and $960 \mathrm{mg} / 100 \mathrm{~g}$ feed $(p=0.000)$. The experimental catfish supplemented with turmeric powder at a dose of $240 \mathrm{mg} / 100 \mathrm{~g}$ feed had absolute body weight gain of $2.81(p=$ $0.000), 1.77(p=0.012)$, and 2.54 times ( $p=$ 0.000) compared to experimental catfish supplemented with turmeric powder at doses of 0,480 , and $960 \mathrm{mg} / 100 \mathrm{~g}$ feed, respectively. At the beginning of experiment, the average body weights of catfish in the groups supplemented with turmeric powder at doses of 0 and 480 $\mathrm{mg} / 100 \mathrm{~g}$ feed were higher compared to those in the groups supplemented with turmeric powder at doses of 240 and $960 \mathrm{mg} / 100 \mathrm{~g}$ feed $(p=0.000)$. Therefore, the differences in absolute body weights of experimental catfish during 12 weeks of turmeric supplementation were not caused by the differences in the body weights of experimental catfish at the beginning of experiment. However, there was an indication that the increase in the dose of turmeric powder supplementation above 240 $\mathrm{mg} / 100 \mathrm{~g}$ feed decreased absolute body weight gain of the experimental catfish. The experimental catfish supplemented with turmeric powder at doses of 480 and 960 $\mathrm{mg} / 100 \mathrm{~g}$ feed had lower absolute body weight gains by $43.52 \%(p=0.012)$ and $60.65 \%(p=$ 0.000 ) compared to those supplemented with turmeric powder at a dose of $240 \mathrm{mg} / 100 \mathrm{~g}$ feed. The experimental catfish supplemented with turmeric powder at doses of 480 ( $p=$ $0.060)$ and $960 \mathrm{mg} / 100 \mathrm{~g}$ feed $(\mathrm{p}=0.285)$ had similar absolute body weight gains even though slightly higher compared to control experimental catfish without turmeric powder supplementation. However, there was a tendency of higher absolute body weight of catfish supplemented with turmeric powder at a dose of $480 \mathrm{mg} / 100 \mathrm{~g}$ feed compared to control experimental catfish without turmeric powder supplementation $(p=0.060)$. Catfish supplemented with turmeric powder at a dose of $480 \mathrm{mg} / 100 \mathrm{~g}$ feed had similar absolute body weight gain compared to those supplemented with turmeric powder at a dose of $960 \mathrm{mg} / 100 \mathrm{~g}$ feed $(p=0.113)$.

Table 1. Averages absolute body weight gain of experimental catfish supplemented with turmeric powder at doses of $0,240,480$, and $960 \mathrm{mg} / 100 \mathrm{~g}$ feed during 12 weeks.

\begin{tabular}{lc}
\hline 0 & $0.77 \pm 0.06^{\mathrm{a}}$ \\
240 & $2.16 \pm 0.46^{\mathrm{b}}$ \\
480 & $1.22 \pm 0.44^{\mathrm{a}}$ \\
960 & $0.85 \pm 0.12^{\mathrm{a}}$ \\
\hline${ }^{\mathrm{ab}}$ Different superscripts in the same column indicate the significant difference between means \\
$(P<0.05)$.
\end{tabular}


The increase in the absolute body weight gain observed in the experimental catfish supplemented with turmeric powder should be related to the increased feed consumption. However, feed intake of experimental catfish in this experiment was not measured since the feed was added into the water in the maintenance ponds. In our previous study, catfish supplemented with turmeric powder at doses of $240-480 \mathrm{mg} / 100 \mathrm{~g}$ feed showed higher body weight gains during 42 days of treatment (Dewi et al., 2018a). Supplementation of $0.2 \mathrm{~g}$ curcumin $/ \mathrm{kg}$ feed also showed an increase in body weight gain in broiler chicken (Rajput et al., 2012). Supplementation of Nigella Sativa combined with turmeric powder at doses of $5-10 \mathrm{~g} / \mathrm{kg}$ feed for 60 days could also increase daily growth rate of the Lates calcarifer fish (Abdelwahab and El Bahr, 2012).

Even though the main target of turmeric supplementation is liver, turmeric supplementation at doses of 240,480 , and 960 $\mathrm{mg} / 100 \mathrm{~g}$ feed did not affect the weights of the liver in the experimental catfish compared to control experimental catfish without turmeric supplementation (with $p=0.846, p=0.234$, and $p=0.170$, respectively) (Table. 2). However, there was a tendency that experimental catfish supplemented with turmeric powder at a dose of $240 \mathrm{mg} / 100 \mathrm{~g}$ feed had the highest weight of liver. Catfish supplemented with turmeric powder at a dose of $240 \mathrm{mg} / 100 \mathrm{~g}$ feed had higher liver weight compared to catfish supplemented with turmeric powder at doses of $480(p=0.009)$ and $960 \mathrm{mg} / 100 \mathrm{~g}$ feed $(p=$ 0.002). The experimental catfish supplemented with turmeric powder at doses of 480 and 960 $\mathrm{mg} / 100 \mathrm{~g}$ feed had liver weights that decreased significantly by $32.27 \%(p=0.009)$ and $36.99 \%$ $(p=.002)$ compared to those supplemented with turmeric powder at a dose of $240 \mathrm{mg} / 100 \mathrm{~g}$ feed. The control experimental catfish without turmeric supplementation and those supplemented with turmeric powder at doses of 480 and $960 \mathrm{mg} / 100 \mathrm{~g}$ feed had similar liver weights ( $p=0.234$ and $p=0.170$, respectively).

The data on the DNA concentrations of liver tissue as an indicator of the number and concentrations of hepatocytes in the liver tissue also showed the similar phenomenon i.e., the supplementation of turmeric powder at doses of 240 to $960 \mathrm{mg} / 100 \mathrm{~g}$ feed did not affect the DNA concentrations in the liver tissue $(p=$ 0.636) (Table 2). Control catfish without turmeric supplementation had similar liver DNA concentrations with catfish supplemented with turmeric powder at doses of $240(p=0.190)$, $480(p=0.956)$, and $960 \mathrm{mg} / 100 \mathrm{~g}$ feed $(p=$ 0.052 ). Catfish supplemented with turmeric powder at a dose of $240 \mathrm{mg} / 100 \mathrm{~g}$ feed had similar liver DNA concentrations with catfish supplemented with turmeric powder at doses of $480(p=0.597)$ and $960 \mathrm{mg} / 100 \mathrm{~g}$ feed $(p=$ 0.650). Increased dose of turmeric supplementation from 480 to $960 \mathrm{mg} / 100 \mathrm{~g}$ feed did not affect liver DNA concentration ( $p=$ 0.485). Similar to the liver weight, the supplementation of experimental catfish with turmeric powder did not affect the populations or concentrations of hepatocytes in the liver tissue. The decreased liver weight observed in the experimental catfish supplemented with turmeric powder at a dose of $960 \mathrm{mg} / 100 \mathrm{~g}$ feed did not show a significant difference in the concentrations of hepatocytes. However, catfish supplemented with turmeric powder at doses of $240(p=0.190)$ and $960 \mathrm{mg} / 100 \mathrm{~g}$ feed $(p=$ 0.052 ) tended to have higher liver DNA concentrations compared to control catfish.

Table 2. Average liver weights, DNA and RNA concentrations of the liver of catfish supplemented with turmeric powder at doses of $0,240,480$, and $960 \mathrm{mg} / 100 \mathrm{~g}$ feed during 12 weeks.

\begin{tabular}{ccccc}
\hline \multirow{2}{*}{ Parameters } & \multicolumn{4}{c}{ Dose of turmeric powder supplementation $(\mathrm{mg} / 100 \mathrm{~g}$ feed $)$} \\
\cline { 2 - 5 } & 0 & 240 & 480 & 960 \\
\hline $\begin{array}{c}\text { Liver weight }(\mathrm{g}) \\
\begin{array}{c}\text { Liver DNA concentration } \\
\left(\mu \mathrm{g} \mathrm{mg}^{-1}\right)\end{array}\end{array}$ & $58.26 \pm 20.02^{\mathrm{ab}}$ & $60.67 \pm 0.46^{\mathrm{a}}$ & $41.09 \pm 7.11^{\mathrm{b}}$ & $38.23 \pm 5.57^{\mathrm{b}}$ \\
$\begin{array}{c}\text { Liver RNA concentration } \\
\left(\mu \mathrm{g} \mathrm{mg}^{-1}\right)\end{array}$ & $9.82 \pm 0.16^{\mathrm{a}}$ & $8.12 \pm 0.19^{\mathrm{a}}$ & $7.85 \pm 0.60^{\mathrm{a}}$ & $8.06 \pm 0.08^{\mathrm{a}}$ \\
& & & \\
${ }^{\mathrm{ab}}$ Different superscripts in the same raw indicate significant difference between means $(\mathrm{P}<0.05)$.
\end{tabular}


In general, control catfish without turmeric supplementation had similar liver RNA concentrations compared to those supplemented with turmeric powder at doses of $240(p=0.238), 480(p=0.291)$, and 960 $\mathrm{mg} / 100 \mathrm{~g}$ feed $(\mathrm{p}=0.151)$. These data indicated that turmeric powder supplementation did not affect the synthetic activities of hepatocytes $(p=0.073)$. However, the increase in turmeric powder supplementation to 960 $\mathrm{mg} / 100 \mathrm{~g}$ feed tended to decrease RNA concentrations in the liver tissue compared to those supplemented with turmeric powder at doses of $0(p=0.151), 240(p=0.085)$, and $480 \mathrm{mg} / 100 \mathrm{~g}$ feed $(p=0.096)$. The highest RNA concentrations in the liver tissue was found in the experimental catfish supplemented with turmeric powder at a dose of $240 \mathrm{mg} / 100 \mathrm{~g}$ feed followed by those supplemented with turmeric powder at a dose of $480 \mathrm{mg} / 100 \mathrm{~g}$ feed and control experimental catfish without turmeric powder supplementation (Table 2).

The MDA concentrations in the liver tissue as an indicator of oxidative stress in the liver tissue also showed a similar phenomenon $(p=0.295)$ i.e., supplementation of turmeric powder did not affect the MDA concentration in the liver tissue, even though numerically decreased with the increased dose of turmeric supplementation. Control catfish without turmeric powder supplementation had similar liver MDA concentrations compared to those supplemented with turmeric powder at doses of $240(p=0.899), 480(p=0.264)$, and 960 $\mathrm{mg} / 100 \mathrm{~g}$ feed $(\mathrm{p}=0.970)$ (Table 3$)$. Liver MDA concentrations of catfish supplemented with $240 \mathrm{mg} / 100 \mathrm{~g}$ feed were similar compared to those supplemented with turmeric powder at doses of $480(p=0.262)$ and $960 \mathrm{mg} / 100 \mathrm{~g}$ feed $(p=0.950)$. Catfish supplemented with turmeric powder at doses of 480 and 960 $\mathrm{mg} / 100 \mathrm{~g}$ feed had similar liver MDA concentrations $(p=0.275)$.

In general, the experimental catfish supplemented with turmeric powder at doses up to $960 \mathrm{mg} / 100 \mathrm{~g}$ feed tended to decrease the SOD activity and concentrations in the liver tissue $(p=0.078)$ (Table 3$)$. Control experimental catfish without turmeric powder supplementation tended to have higher liver SOD concentrations as an indicator of endogenous antioxidant compared to catfish supplemented with turmeric powder at doses of 240 (0.067), $480(p=0.101)$, and $960 \mathrm{mg} / 100 \mathrm{~g}$ feed $(p=0.079)$. However, catfish supplemented with turmeric powder at a dose of $240 \mathrm{mg} / 100 \mathrm{~g}$ feed had similar liver SOD concentrations compared to those supplemented with turmeric powder at doses of $480(p=0.374)$ and $960 \mathrm{mg} / 100 \mathrm{~g}$ feed $(p=$ 0.288). Increased dose of turmeric powder supplementation from 480 to $960 \mathrm{mg} / 100 \mathrm{~g}$ feed did not affect liver SOD concentration ( $p=$ 0.163 ).

Table 3. Liver MDA and SOD concentrations and blood SGPT and SGOT concentrations of experimental catfish supplemented with turmeric powder at doses of $0,240,480$, and $960 \mathrm{mg} / 100 \mathrm{~g}$ feed during 12 weeks.

Parameters Dose of turmeric powder supplementation $(\mathrm{mg} / 100 \mathrm{~g}$ feed)

\begin{tabular}{lcccc} 
& 0 & 240 & 480 & 960 \\
\hline $\begin{array}{l}\text { Liver MDA } \\
\text { concentration }\left(\mathrm{mg} \mathrm{kg}^{-1}\right)\end{array}$ & $1.83 \pm 0.46^{\mathrm{a}}$ & $1.55 \pm 0.21^{\mathrm{a}}$ & $1.57 \pm 0.67^{\mathrm{a}}$ & $1.52 \pm 0.76^{\mathrm{a}}$ \\
$\begin{array}{l}\text { Liver SOD } \\
\text { concentration }\left(\mathrm{mg} \mathrm{kg}^{-1}\right)\end{array}$ & $12.12 \pm 0.42^{\mathrm{a}}$ & $11.90 \pm 0.72^{\mathrm{a}}$ & $11.39 \pm 0.41^{\mathrm{a}}$ & $9.45 \pm 1.92^{\mathrm{a}}$ \\
$\begin{array}{l}\text { Plasma SGPT } \\
\text { concentration (U/L) }\end{array}$ & $81.23 \pm 2.19^{\mathrm{a}}$ & $17.77 \pm 8.79^{\mathrm{b}}$ & $15.23 \pm 3.81^{\mathrm{b}}$ & $47.89 \pm 36.55^{\mathrm{ab}}$ \\
$\begin{array}{l}\text { Plasma SGOT } \\
\text { concentration (U/L) }\end{array}$ & $66.32 \pm 16.77^{\mathrm{a}}$ & $23.78 \pm 17.21^{\mathrm{b}}$ & $44.72 \pm 12.43^{\mathrm{ab}}$ & $30.22 \pm 13.40^{\mathrm{b}}$ \\
\hline $\begin{array}{l}{ }^{\mathrm{b}} \text { Different superscripts in the same row indicate significant difference between means }(\mathrm{P}<0.05) .\end{array}$
\end{tabular}


Supplementation of turmeric powder significantly decreased SGPT $(p=0.009)$ activities and concentrations in the plasma of experimental catfish (Table 3). The experimental catfish supplemented with turmeric powder at doses of 240 and 480 $\mathrm{mg} / 100 \mathrm{~g}$ feed significantly decreased SGPT concentrations in the plasma by $78.12 \%(p=$ $0.000)$ and $81.25 \%(p=0.000)$ compared to control experimental catfish without turmeric supplementation. However, the experimental catfish supplemented with turmeric powder at a dose of $960 \mathrm{mg} / 100 \mathrm{~g}$ feed had similar plasma SGPT concentrations compared to experimental catfish supplemented with turmeric powder at doses of $0(p=0.190), 240$ $(p=0.237)$, and $480 \mathrm{mg} / 100 \mathrm{~g}$ feed $(P=0.199)$. However, the increased dose of turmeric powder supplementation to $960 \mathrm{mg} / 100 \mathrm{mg}$ feed tended to decrease SGPT concentrations in the plasma by $41 \%(p=0.190)$ compared to control experimental catfish without turmeric supplementation. Increased dose of turmeric powder supplementation from 240 to 480 $\mathrm{mg} / 100 \mathrm{~g}$ feed did not affect plasma SGPT concentration $(p=0.670)$.

Similar to the plasma SGPT concentration, plasma SGOT concentrations of experimental catfish significantly decreased with the supplementation of turmeric powder $(p$ $=0.036$ ). Catfish supplemented with turmeric powder at doses of 240 and $960 \mathrm{mg} / 100 \mathrm{~g}$ feed significantly had decreased plasma SGOT concentrations by $64.14 \%(p=0.037)$ and $54.43 \%(p=0.044)$, respectively, compared to control catfish without turmeric powder supplementation. The experimental catfish supplemented with turmeric powder at dose of $480 \mathrm{mg} / 100 \mathrm{~g}$ feed had numerically lower plasma SGOT concentrations by $32.57 \%$ ( $p=$ .148) compared to control experimental catfish without turmeric supplementation. However, the experimental catfish supplemented with turmeric powder at doses of $960 \mathrm{mg} / 100 \mathrm{~g}$ feed had similar plasma SGOT concentrations compared to catfish supplemented with turmeric powder at doses of $240(p=0.636)$ and 480 $\mathrm{mg} / 100 \mathrm{~g}$ feed $(\mathrm{p}=0.241)$ (Table 3$)$. Catfish supplemented with turmeric powder at a dose of $480 \mathrm{mg} / 100 \mathrm{~g}$ feed had similar plasma SGOT concentrations compared to catfish supplemented with turmeric powder at doses of $0(p=0.148)$ and $240 \mathrm{mg} / 100 \mathrm{~g}$ feed $(p=$ $0.163)$.

The increased liver weight and body weight were similar to the increased DNA concentrations of the liver tissue. The increase in liver weight indicated that turmeric powder supplementation was assumed to improve liver function, by increasing the regeneration of hepatocytes and protected liver and hepatocytes from the effect of toxic compounds that destroy the liver functions. The increased liver weight, body weight, and DNA concentrations of the liver tissues are related to the role of curcumin found in the turmeric powder that can induce growth factors and the other enzymes. Supplementation of turmeric powder at a dose of $54 \mathrm{mg} /$ day in quail could increase the liver function that was shown by the decreased the destruction of hepatocytes and increased the growth of hepatocyte (Saraswati et al., 2013).

The increase in RNA concentrations of liver tissue found in the present experiment indicated the increased protein synthetic activity of the hepatocytes. The increase in serum protein concentrations was also found in layer chickens (Radwan et al., 2008), quail (Saraswati et al., 2013), and broiler chickens (Kumari et al., 2007).

The decrease in MDA concentrations of liver tissue of experimental catfish indicates the inhibition and reduction of free radical production by curcumin found in the turmeric powder. The changes in liver cells and hepatocytes are caused by the antioxidant activities of turmeric powder. Turmeric has a strong potency of antioxidant that is shown by the ability to trap and clean free radicals by cutting oxidant chains (Radwan et al., 2008). Curcumin has antioxidant activity by inhibiting the activities of inflammation enzymes (Akram et al., 2010). Radwan et al. (2008) reported that turmeric powder supplementation by 0.5 and $1 \%$ in laying hens decreased the MDA concentrations and contents in the egg. Curcumin supplementation by 0.5 and $1 \%$ in ration with $40 \%$ protein with 2 and 8 weeks of administration in Anabas testudineus (Bloch) fish showed the increase in the antioxidant status of hepatocytes of hepatopancreas and increase in the concentration of glutathione (Manju et al., 2012; Manju et al., 2013).

Turmeric powder supplementation at a dose of $240 \mathrm{mg} / 100 \mathrm{~g}$ feed showed the optimum results in improving the physiological conditions of experimental catfish that was shown by the improved liver function as was shown in the increased vitellogenin synthesis (Dewi et al., 2018a,b). The best hepatoprotector activity of turmeric powder was shown by the decrease in SGPT and SGOT in the experimental catfish supplemented with turmeric powder at a dose of $240 \mathrm{mg} / 100 \mathrm{~g}$ feed compared to control experimental catfish without turmeric powder supplementation. The study using curcumin as a hepatoprotector 
showed the positive effect of curcumin in the liver as was shown by the decreased serum concentrations of SGPT and SGOT (Gandhi et al., 2011). Saraswati et al. (2013) showed that

Component of curcumin is very important as a hepatoprotector to protect hepatocytes from destruction caused by the free radicals, as was indicated by the decrease in the serum the increase in turmeric powder supplementation up to $54 \mathrm{mg} /$ quail/day showed the optimal results in improving the physiological conditions of quails. The bioactive SGPT and SGOT concentrations in the ducks supplemented with curcumin (Kasiyati et al. 2016).

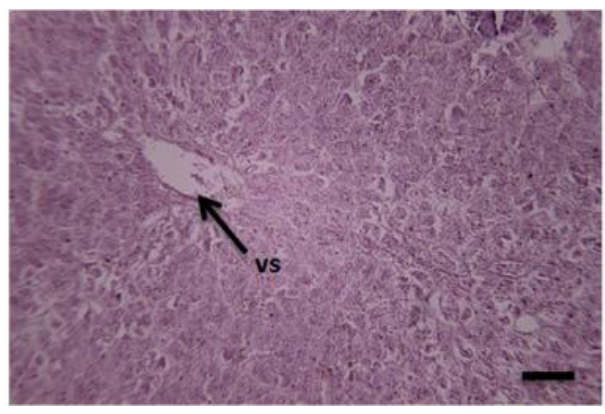

KO

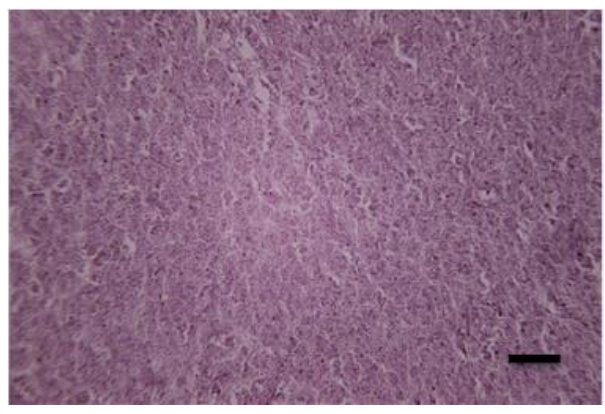

K2

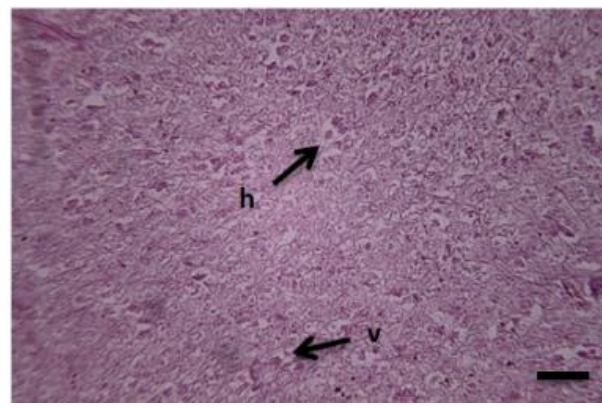

$\mathrm{K} 1$

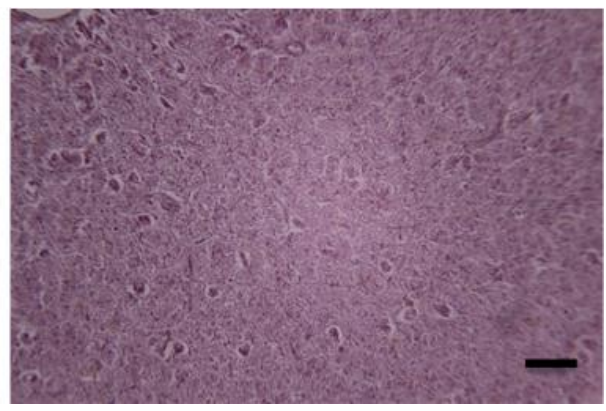

K3

Figure 1. Histology of liver of experimental catfish supplemented with turmeric powder at doses of 0 $\mathrm{mg} / 100$ feed (K0), $240 \mathrm{mg} / 100 \mathrm{~g}$ feed (K1), $480 \mathrm{mg} / 100 \mathrm{~g}$ feed (K2), and $960 \mathrm{mg} / 100 \mathrm{~g}$ feed (K3). Hepatocyte (h), central vein (vs), vacuole (v). Staining with H\&E, Scale line represented $50 \mu \mathrm{m}$. Enlargement $40 \times 10$ times.

The histological analyses of liver were conducted to evaluate the liver conditions during vitellogenesis. Histological observations in the experimental catfish showed that turmeric powder supplementation in the experimental catfish increased the deposition of egg yolk precursor, vitellogenin, in the cytoplasm as was shown by the increased number of vacuoles in the cytoplasm of hepatocytesite (Figure 1). This condition confirmed that turmeric powder supplementation in catfish during gonad maturity improved the functions of hepatocytes and improved and increased the synthetic activity and capacity of hepatocytes to synthesize and produce vitellogenin as a precursor of egg yolk (Dewi et al., 2018a,b).

\section{Conclusion}

Based on the results obtained it was concluded that turmeric powder supplementation at a dose of $240 \mathrm{mg} / 100 \mathrm{~g}$ feed can improve the liver functions. The improved liver functions was supported by the increased body weight gain, liver weight, and DNA concentrations of liver tissue, as well as the decrease in MDA in the liver tissue and serum SGPT and SGOT concentrations in the blood of experimental catfish. Turmeric powder supplementation can be used to increase liver functions that will increase synthetic activities and capacities of hepatocytes to synthesize vitellogenin during reproductive phase of oviparous animals. 


\section{References}

Abdelwahab, A.M., El-Bahr, S.M. 2012. Influence of black cumin seeds (Nigella sativa) and turmeric (Curcuma longa linn.) mixture on performance and serum biochemistry of Asian sea bass, Lates calcarifer. World Journal of Fish and Marine Sciences 4 (5): 496-503.

Aggarwal, B.B., Sudaram, C., Malani, N., Ichikawa H. 2006. Curcumin: The Indian solid gold. SVNY-Aggarawal 16:34.

Akram, M., Uddin, S., Ahmed, A., Usmanghani, K., Hannan, A., Mohiuddin, E., Asif, M. 2010. Curcuma longa and curcumin: $A$ review article. Rom J.Biol-Plant Biol 55(2): 65-70.

Al-Sultan, S.I. 2003. The effect of Curcuma longa (tumeric) on overall performance of broiler chickens. Int J Poult Sci 2(5): 351-353.

Bancroft, J.D., Gamble, M. 2008. Theory and Practice of Histological Techniques. 6th Ed. Churcill Livingstone, China: Elsevier.

Bigoniya, P., Singh, C.S., Shukla, A. 2009. A comprehensive review of different liver toxicants used in experimental pharmacology. International Journal of Pharmaceutical Sciences and Drug Research 1(3): 124-135.

Biswas, A., Mohan, J.,Venkata, K., Sastry, H. 2010. Age-dependent variation in hormonal concentration and biochemical constituents in blood plasma of Indian native fowl. Vet Med Int :737292. 10.4061/2010/737292.

Capeyron, M.F.M., Julie, C., Eric, B., Jean, P., Jean, M.R., Piere, B. 2002. A diet cholesterol and deficient in vitamin $E$ induces lipid peroxidation but doses not enhance antioxidant enzyme expression in rat liver. $\mathrm{J}$ Nutr Biochem 13: 296-301.

Dewi, C.D., Ekastuti, D.R., Sudrajat, A.O., Manalu, W. 2018a. Improved vitellogenesis, gonad devalopment and egg diameter in catfish (Pangasionodon hypopthalmus) supplemented with tumeric (Curcuma longa) powder. Aquaculture Research 49(2):651-658.

Dewi, C.D., Ekastuti, D.R., Sudrajat, A.O., Manalu, W. 2018b. Increased vitellogenin synthesis, fecundity, egg diameter, fertilization rate and hatching rate of eggs and increased survival rate of larvae produced by catfish (Pangasionodon hypopthalmus) supplemented with tumeric (Curcuma longa) powder. Unpublished.

Echols, M. 2006. Liver disease-diagnosis and management. Proceedings, of the North American Veterinary Conference. January 7-11, 2006. Small Animal Ed. P. 20: 151-153. Orlando, Folorida.

Gandhi, P., Khan, Z., Chakraverty, N. 2011. Soluble curcumin: a promising oral suplement for health management. $\mathrm{J}$ App Pharm Sci 01(02): 01-07.

Gorman, K.B., Esler, D., Walzem, R.L., Williams, T.D. 2008. Plasma Yolk Precursor Dynamics during Egg Production by Female Greater Scaup (Aythya marila): Characterization and Indices of Reproductive State. Electronically Published 12/31/2008.

Kasiyati, Manalu, W., Sumiati, Ekastuti, D.R. 2016 Efficacy of curcumin and monochromatic light in improving liver function of sexually mature magelang ducks. Journal of the Indonesian Tropical Animal Agriculture 41(3): 153160.

Kumari, P., Gupta, M.K., Ranjan, R., Singh, K.K., Yadava, R. 2007. Curcuma longa as feed additive in broiler birds and its patho-physiological effects. Indian $\mathrm{J}$ Exp Biol 45:272-277.

Kohli, K., Ali, J., Ansari, M.J., Raheman, Z. $2005 . \quad$ Curcumin: Anatural antiinflammatory agent. Indian $\mathrm{J}$ Pharmacol 37 (3): 141-147.

Manalu, W., Sumaryadi, M.Y. 1998. Maternal serum progesterone concentration during gestation and mammary gland growth and development at parturition in Javanese thin-tail ews wth carrying a single or multiple fetuses. Small. Rum. Res 27:131-136.

Manju, M., Vijayasree, A.S., Akbarsha, M.A., Oomen, O.V. 2013. Protective effect of dietary curcumin in Anabas testudineus (Bloch). Fish Physiology and Biochemistry 39:1323-1330

Manju, M., Akbarsha, M.A., Oommen, O.V. 2012. In vivo protective effect of dietary curcumin in fish Anabas testudineus (Boch). Fish Physiology and Biochemistry. 38: 309-318. 
Radwan, N., Hassan, R.A., Qota, E.M., Fayek, H.M. 2008. Effect of natural antioxidant on oxidative stability of eggs and productive and reproductive performance of laying hens. Int $\mathrm{J}$ Poult Sci 7:134-150.

Rajput, N., Muhammah, N., Yan, R., Zhong, X., Wang, T. 2012. Effect of dietary supplementation of curcumin on growth performance, intestinal morphology and nutrients utilization of broiler chicks. Int J Poult Sci 50: 44-52.
Saraswati, T.R., Manalu, W., Ekastuti, D.R., Kusumorini, N. 2013. Increased egg production of japanese quail (cortunix japonica) by improving liver function through turmeric powder supplementation. Int J Poult Sci 12 (10): 601-614.

Somchit, M.N., Zuraini, A., Bustamam, A., Sulaiman, M.R., Nuratunlina, R. 2005.Protective activity of turmeric (Curcuma longa) in paracetamol induced-hepatotoxicity in rat. Int $\mathrm{J}$ of pharm 1(3): 252-256 